\title{
Molecular Epidemiology of Pseudomonas syringae pv. syringae Causing Bacterial Leaf Spot of Watermelon and Squash in Florida
}

\author{
E. A. Newberry and B. Babu, North Florida Research and Education Center, University of Florida, Quincy; P. D. Roberts, Southwest Florida \\ Research and Education Center, University of Florida, Immokalee; N. S. Dufault, E. M. Goss, and J. B. Jones, ${ }^{\dagger}$ Department of Plant Pathol- \\ ogy, University of Florida, Gainesville; and M. L. Paret, ${ }^{\dagger}$ North Florida Research and Education Center, University of Florida, Quincy
}

\begin{abstract}
From 2013 to 2014, bacterial leaf spot epidemics incited by Pseudomonas syringae pv. syringae affected an estimated 3,000 ha of watermelon and squash in Florida, and caused foliar blighting and transplant losses in severely affected fields. To investigate the diversity of the causal agent, we isolated $28 P$. syringae strains from diseased plants grown in 10 Florida and Georgia counties over the course of 2 years. Strains were confirmed as $P$. syringae through sequence analysis of the $16 \mathrm{~S}$ ribosomal RNA, phenotypic, and biochemical profiling; however, 20 displayed an atypical phenotype by exhibiting nonfluorescent activity on King's medium B agar and being negative for ice-nucleating activity. Multilocus sequence analysis and BOX

polymerase chain reaction revealed the presence of two haplotypes among the collected strains that grouped into two distinct clades within $P$. syringae phylogroup 2. Pathogenicity testing showed that watermelon, cantaloupe, and squash seedlings were susceptible to a majority of these strains. Although both haplotypes were equally virulent on cantaloupe, they differed in virulence on watermelon and squash. The distribution of one haplotype in 9 of 10 Florida and Georgia counties sampled indicated that these epidemics were associated with the recent introduction of a novel clonal $P$. syringae lineage throughout major watermelon production areas in Florida.
\end{abstract}

Florida is consistently among the top producers of watermelon nationally, with 8,500 to 10,500 ha harvested in the state from year to year (FDACS 2012, 2014). Numerous fungal and viral diseases are common to Florida watermelon production; however, bacterial diseases are sporadic and generally considered to be of minor importance (Elwakil and Mossler 2013). In spring 2013, a new disease outbreak of bacterial leaf spot caused by Pseudomonas syringae was observed on watermelon and squash in major production areas throughout the state (Newberry et al. 2015). From 2013 to 2014, this disease affected an estimated 3,000 ha of the crop, with incidence reported from southern Georgia to southern Florida. In some fields, foliar blighting was observed at the early stages of seedling development and resulted in transplant losses and delayed fruiting of severely blighted seedlings.

Bacterial leaf spot of watermelon was first identified in Florida in 1963, where the causal agent was formally described as $P$. syringae pv. lachrymans (Hopkins and Schenck 1972; Mullin and Schenck 1963). Since that time, different members of the $P$. syringae species complex have been recovered periodically as leaf spot pathogens of watermelon, cantaloupe, and squash in the southeastern United States (Langston et al. 2003; Newberry et al. 2016). P. syringae is a gramnegative member of the class Gammaproteobacteria, and is responsible for numerous plant diseases worldwide (Bradbury 1986; Young 2010). Due to the inability to differentiate distinct pathogenic $P$. syringae populations with traditional biochemical and physiological tests, members of the species were classified at the infrasubspecific level into over 50 pathovars as defined by their distinctive pathogenicity and host range specialization (Young 2010). Worldwide, P. syringae pvs. lachrymans, syringae, and aptata have been identified as the causal agents of epidemics affecting various cucurbit species (Fatmi et al. 2008; Harighi 2007; Langston et al. 2003; Morris et al. 2000; Sedighian et al. 2014). In many cases, these epidemics were reported in a region where the

${ }^{\dagger}$ Corresponding authors: M. L. Paret; E-mail: paret@ufl.edu; and J. B. Jones; E-mail: jbjones@ufl.edu

*The $\boldsymbol{e}$-Xtra logo stands for "electronic extra" and indicates that two supplementary figures are published online.

Accepted for publication 18 September 2017.

C 2018 The American Phytopathological Society disease was previously unobserved, and were associated with greenhouse production or crops grown under plastic tunnels (Fatmi et al. 2008; Harighi 2007; Morris et al. 2000; Sedighian et al. 2014). Often, the disease did not reoccur the following season. However, there have been reports where the pathogen continued to be a problem, threatening the sustainability of cucurbit production in a region for subsequent seasons (Fatmi et al. 2008; Morris et al. 2000).

Seed infestation is recognized as a major factor contributing to longdistance dissemination of $P$. syringae in vegetable crops (Lamichhane et al. 2015). In 2011, the United States imported 146,000 kg of watermelon seed from 10 different countries, valued at \$269 million (USDA 2013). As global trade associated with agricultural production increases, so too does the potential for the unintentional introduction of seedborne pathogens into agricultural ecosystems (Schaad et al. 2014). P. syringae, an environmentally ubiquitous bacterial species, may have multiple sources of dissemination. Bacterial blight epidemics occurring in French cantaloupe fields were linked to precipitation and irrigation water rather than contaminated seed, thus suggesting that the epidemiological significance of environmental inoculum sources may be overlooked in bacterial disease outbreaks (Monteil et al. 2016; Riffaud and Morris 2002).

Over the past 15 years, phylogenetic analyses using various molecular markers have been conducted to investigate the relationships of P. syringae pathovars (Berge et al. 2014; Bull et al. 2011; Hwang et al. 2005; Sarkar and Guttman 2004; Yamamoto et al. 2000). These studies have shown $P$. syringae to be a phylogenetic complex of strains subdivided into 13 phylogroups on the basis of sequence divergence. Phylogroups 1 through 8 include most of the recognized pathovars and pathotype strains while the remaining phylogroups comprise strains primarily recovered from environmental sources (Berge et al. 2014). A survey of $P$. syringae strains isolated from symptomatic cucurbit tissue between 1999 and 2011 identified the population associated with disease in the United States to be genetically diverse, and primarily distributed among three clades within $P$. syringae phylogroup 2 . This study also reported the presence of a novel $P$. syringae haplotype common to Florida, Georgia, and California that was isolated from several different cucurbit hosts (Newberry et al. 2016).

Recent epidemics of bacterial leaf spot affecting watermelon and squash in Florida were distinct from previously recorded disease outbreaks in the southeastern United States in terms of their scale and severity. The consequences associated with the introduction of exotic pathogens into agricultural ecosystems can be devastating for an 
industry. Therefore, a knowledge of the pathogen diversity is essential to provide insight into potential modes of dissemination. To investigate the population structure of the pathogen associated with recent bacterial leaf spot epidemics, we collected $28 P$. syringae strains from diseased fields in 10 different Florida and Georgia counties over the course of 2 years. Here, we provide evidence indicating that these epidemics were caused by two genetically distinct and clonal $P$. syringae lineages that were recently introduced and rapidly spread throughout major watermelon production areas in Florida.

\section{Materials and Methods}

Bacterial strain collection. Symptomatic leaf tissue was collected from commercial production fields of watermelon and squash grown in Florida and Georgia during the spring 2013 and 2014 seasons (Fig. 1). Sections (approximately $1 \mathrm{~cm}^{2}$ ) of leaf tissue were aseptically cut at the margin of lesions, surface sterilized by washing in $0.6 \%$ sodium hypochlorite for $1 \mathrm{~min}$, and rinsed two times with sterile tap water. Leaf tissue was then macerated in sterile tap water and streaked on nutrient agar and King's medium B agar (KB). After $48 \mathrm{~h}$ of incubation at $28^{\circ} \mathrm{C}$, single colonies were subcultured on $\mathrm{KB}$ and pure cultures were obtained for further characterization. Preliminary identification of the recovered bacterial strains was conducted through sequence analysis of the 16S ribosomal RNA (rRNA) and the ability to induce a hypersensitive response (HR) on tobacco leaves (Gürtler and Stanisich 1996). All strains that were identified as members of the Pseudomonas genus and HR-positive were preserved in a $30 \%$ glycerol solution at $-80^{\circ} \mathrm{C}$ for long-term storage and, subsequently, subjected to further analysis. The bacterial strains collected in this study are listed in Table 1.

Phenotypic characterization. Bacterial strains were assessed for fluorescence on KB and the LOPAT tests, which consist of levan production, oxidase reaction, potato soft rot ability, arginine dihydrolase production, and tobacco hypersensitivity (Lelliott et al. 1966). Copper sensitivity was determined according to a previously described method (Menkissoglu and Lindow 1991). First, the bacterial strains were cultured on plates of casitone yeast extract-glycerol agar (CYEG) amended with $\mathrm{CuSO}_{4} \cdot 5 \mathrm{H}_{2} \mathrm{O}$ at $1 \mu \mathrm{g} \mathrm{ml}^{-1}$. After incubation at $28^{\circ} \mathrm{C}$ for $24 \mathrm{~h}$, bacterial cells were removed from the plates and suspended in sterile deionized water. The cell suspensions were adjusted to approximately $1 \times 10^{8} \mathrm{CFU} \mathrm{ml} \mathrm{m}^{-1}$ spectrophotometrically (optical density at $600 \mathrm{~nm}=0.3$ ), then diluted to a concentration of $10^{7} \mathrm{CFU} \mathrm{ml}{ }^{-1}$. Three $10-\mu l$ droplets were placed on CYEG agar plates amended with concentrations of $\mathrm{CuSO}_{4} \cdot 7 \mathrm{H}_{2} \mathrm{O}$ at $0,5,10,15,20,30$, 40, 50, 60, and $70 \mu \mathrm{g} \mathrm{ml}^{-1}$. Strains were incubated at $28^{\circ} \mathrm{C}$ and the plates were observed for growth after $48 \mathrm{~h}$. Two $P$. syringae strains (DC3000 and A1513), which were previously identified as copper-sensitive and -resistant, respectively, were included as controls (Andersen et al. 1991; Feil et al. 2005). Ice nucleation activity (INA) of the bacterial strains was tested by culturing strains in a broth containing $0.01 \%$ casamino acids, $1.0 \%$ peptone, and $1.0 \%$ glucose at $24^{\circ} \mathrm{C}$ to the stationary growth phase. Bacterial suspensions were then kept at $4^{\circ} \mathrm{C}$ for 2 to $4 \mathrm{~h}$ prior to testing. Five $10-\mu \mathrm{l}$ droplets of the colonized broth were placed onto aluminum foil on an ice-ethanol bath cooled to $-12^{\circ} \mathrm{C}$. Strains were considered to be INA positive if

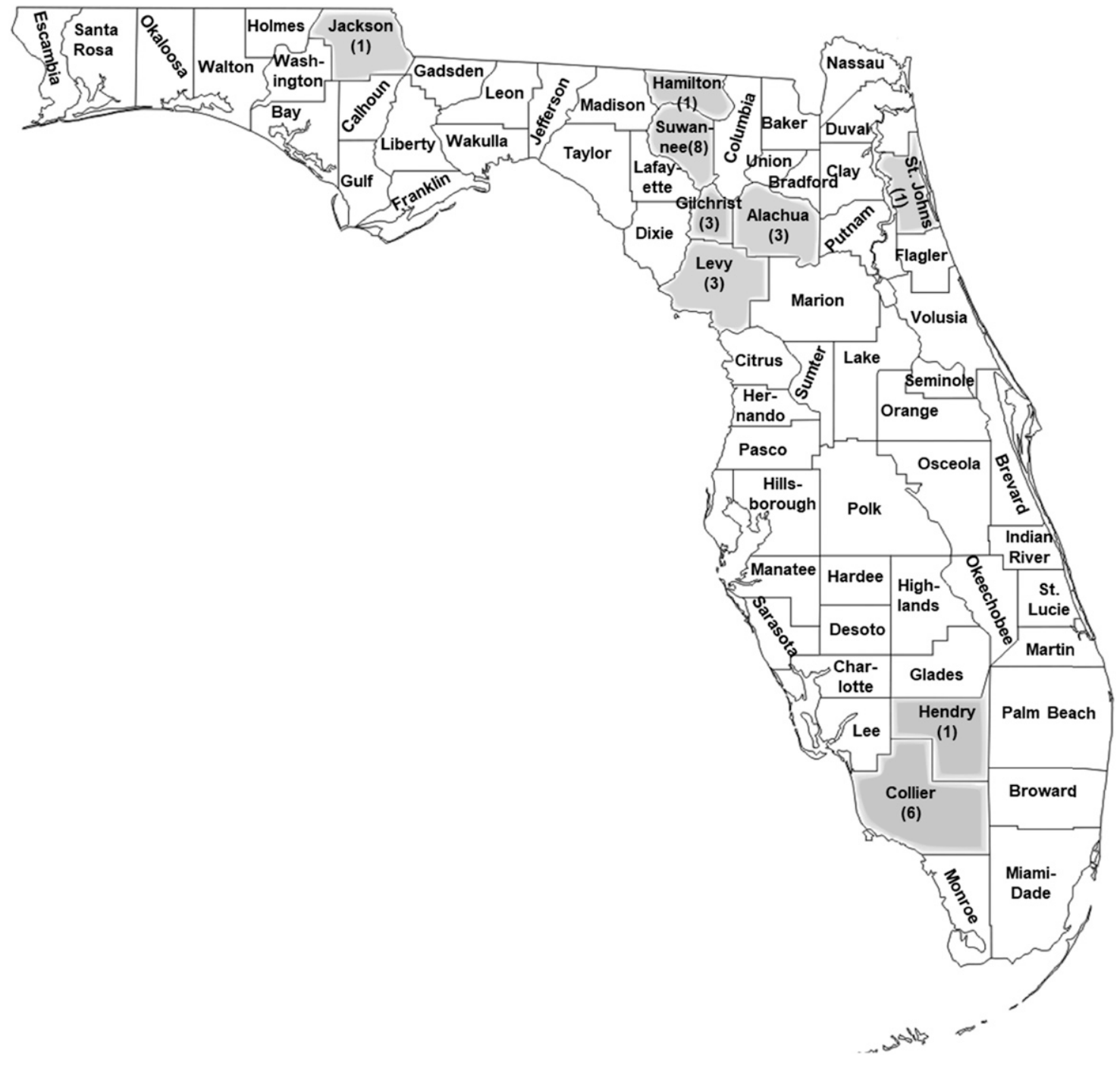

Fig. 1. Map of Florida, with gray-shaded regions indicating the counties where the symptomatic leaf samples were collected. Numbers of strains isolated are indicated in parentheses $(n=28)$; strain 13-1 was collected from Tift County, GA and is not pictured here. 
all five droplets froze within $30 \mathrm{~s}$. Droplets of the uncultured broth were used as a negative control and all phenotypic tests were repeated twice

Multilocus sequence-typing and analysis. Multilocus sequencetyping (MLST) was performed on the 28 P. syringae strains collected from the 2013-14 epidemic using four housekeeping genes $(g y r \mathrm{~B}$, rpoD, gltA, and gap 1 ) according to the MLST schema described by Hwang et al. (2005). Amplicon sequences were trimmed to the same size, concatenated, and aligned with Mega 6 software (Tamura et al. 2013). A maximum-likelihood phylogeny was constructed with the sequences of $59 P$. syringae strains from phylogroups 2 and 3 obtained from the Plant-Associated Microbes Database (PAMDB) and 3 additional strains from the National Center for Biotechnology Information (NCBI) GenBank. This analysis included publicly available sequences of $16 P$. syringae strains previously isolated from symptomatic cucurbit tissue in the United States and France prior to 2013 (Table 2). Due to their association as cucurbit pathogens or genetic similarity to the strains sequenced in this study, the housekeeping gene sequence fragments of $P$. syringae strains HS191, CC457, and CC94 were extracted from the genomes available from NCBI with the following locus tags for each strain, respectively: gyrB: NZ_CP006256, AVEB02000356, and AVEA02000299; rpoD: NZ_CP006256, AVEB02000313, and AVEA02000508; gltA: NZ_CP006256.1, AVEB02000011, and AVEA02000519; and gap1: NZ_CP006256, AVEB02000099, and AVEA02000560. Model selection for the phylogenetic analysis was determined using the Akaike Information Criterion (Burnham and Anderson 2004), and the evolutionary history was inferred using the General TimeReversible model (Nei and Kumar 2000). The multilocus sequence data for the strains collected in this study were deposited in the
PAMDB and NCBI databases with the following accession numbers: gyr $\mathrm{B}=\mathrm{MF} 370398$ to MF370425, rpoD $=\mathrm{MF} 370426$ to MF370453, glt $\mathrm{A}=\mathrm{MF} 370454$ to MF370481, and gap $1=\mathrm{MF} 370482$ to MF370509.

Genotypic characterization using BOX polymerase chain reaction. BOX polymerase chain reaction (PCR) analysis was conducted as described by (Versalovic et al. 1994) for all strains collected in this study. The PCR assay was performed in an Eppendorf Mastercycler gradient $\mathrm{ES}$ and the cycling conditions consisted of 1 initial cycle at $95^{\circ} \mathrm{C}$ for $7 \mathrm{~min} ; 30$ cycles of denaturation at $94^{\circ} \mathrm{C}$ for $1 \mathrm{~min}$, annealing at $53^{\circ} \mathrm{C}$ for $1 \mathrm{~min}$, and extension at $65^{\circ} \mathrm{C}$ for $8 \mathrm{~min}$; followed by a single final extension cycle at $65^{\circ} \mathrm{C}$ for $15 \mathrm{~min}$. Template DNA consisted of cell suspensions adjusted to $10^{8} \mathrm{CFU} \mathrm{ml}{ }^{-1}$ and treated at $95^{\circ} \mathrm{C}$ for $10 \mathrm{~min}$ in sterile deionized water. The cell suspension $(2 \mu \mathrm{l})$ was added to each $23-\mu l$ aliquot of reaction mixture, which contained $1 \times$ Gitschier buffer, $0.4 \mu \mathrm{M}$ primer, $0.8 \mathrm{mM}$ deoxynucleotide triphosphate (Sigma-Aldrich, St. Louis), $2.75 \mathrm{mM}$ bovine serum albumin (Promega Corp., Madison, WI), 10\% dimethyl sulfoxide (Sigma-Aldrich), and 2.5 U of DNA polymerase (Promega Corp.). DNA fragments were separated on a $1.5 \%$ agarose gel, stained with ethidium bromide, and photographed with a UV-gel documentation system (Alpha Imager; ProteinSimple, Santa Clara, CA).

Pathogenicity assays. The pathogenicity of the bacterial strains was evaluated on two-week-old seedlings of watermelon (Citrullus lanatus 'Wrigley'; Seminis Vegetable Seeds, St. Louis), cantaloupe (Cucumis melo L. 'Aphrodite'; Syngenta-U.S., Greensboro, NC), and squash (Cucurbita pepo 'Conqueror III'; Seminis Vegetable Seeds). Inoculum was prepared from bacterial strains cultured on $\mathrm{KB}$ for 24 to $48 \mathrm{~h}$ at $28^{\circ} \mathrm{C}$. Bacterial cells of cultures were suspended in sterile tap water and the resulting cell suspension was adjusted to

Table 1. Pseudomonas syringae strains collected in this study, including their geographical origin, year and host of isolation, phenotypic characteristics, multilocus haplotype, phylogroup classification, and the mean disease severity rating on watermelon (WM), cantaloupe (CL), and squash (SQ) ${ }^{\text {a }}$

\begin{tabular}{|c|c|c|c|c|c|c|c|c|c|c|}
\hline \multirow[b]{2}{*}{ Strain } & \multicolumn{3}{|c|}{ Source of strain } & \multirow[b]{2}{*}{ Fluor } & \multirow[b]{2}{*}{ INA } & \multirow[b]{2}{*}{ Hap } & \multirow[b]{2}{*}{ Phyl } & \multicolumn{3}{|c|}{ Mean severity ratingb } \\
\hline & County ${ }^{\mathrm{c}}$ & Year & Host & & & & & WM (5.70) & CL (5.88) & SQ (4.96) \\
\hline $13-1$ & Tift & 2013 & WM & - & - & 1 & $2 b$ & $5.33 \pm 0.82$ & $7.83 \pm 0.41 * *$ & $6.83 \pm 1.47^{* * *}$ \\
\hline $13-127 \mathrm{~A}$ & Jackson & 2013 & WM & - & - & 1 & $2 b$ & $4.50 \pm 1.87$ & $5.67 \pm 0.52$ & $5.17 \pm 1.33$ \\
\hline 13-139A & Suwannee & 2013 & WM & + & + & 2 & $2 \mathrm{a}$ & $7.17 \pm 1.17 * *$ & $7.33 \pm 0.82$ & $4.00 \pm 0.63$ \\
\hline 13-139B & Suwannee & 2013 & WM & + & + & 2 & $2 \mathrm{a}$ & $6.67 \pm 1.03$ & $6.33 \pm 1.51$ & $4.67 \pm 1.03$ \\
\hline $13-140 \mathrm{~A}$ & Suwannee & 2013 & WM & - & - & 1 & $2 b$ & $5.33 \pm 0.82$ & $6.67 \pm 1.21$ & $5.00 \pm 0.63$ \\
\hline $13-141 \mathrm{~A}$ & Suwannee & 2013 & WM & + & + & 2 & $2 \mathrm{a}$ & $5.83 \pm 0.98$ & $7.67 \pm 0.52 * *$ & $4.83 \pm 1.47$ \\
\hline $13-217 \mathrm{~A}$ & Suwannee & 2013 & WM & + & + & 2 & $2 \mathrm{a}$ & $7.00 \pm 0.89$ & $6.83 \pm 0.98$ & $5.00 \pm 0.00$ \\
\hline 13-217B & Suwannee & 2013 & WM & + & + & 2 & $2 a$ & $6.83 \pm 1.60$ & $5.00 \pm 1.10$ & $4.00 \pm 0.00$ \\
\hline $13-425$ & Levy & 2013 & WM & - & - & 1 & $2 b$ & $6.33 \pm 1.03$ & $5.17 \pm 0.41$ & $4.83 \pm 0.75$ \\
\hline $13-426$ & Gilchrist & 2013 & WM & - & - & 1 & $2 b$ & $5.50 \pm 1.05$ & $6.50 \pm 1.38$ & $4.83 \pm 0.41$ \\
\hline $13-427$ & Alachua & 2013 & WM & - & - & 1 & $2 b$ & $3.50 \pm 0.55^{*}$ & $7.00 \pm 0.89$ & $4.00 \pm 0.89$ \\
\hline $13-428$ & Alachua & 2013 & WM & + & + & 2 & $2 \mathrm{a}$ & $4.83 \pm 1.72$ & $4.67 \pm 0.82 *$ & $3.50 \pm 1.38$ \\
\hline $13-429$ & St. Johns & 2013 & WM & + & + & 2 & $2 \mathrm{a}$ & $7.50 \pm 0.84 * *$ & $7.50 \pm 0.84 * *$ & $3.83 \pm 0.75$ \\
\hline $13-509 \mathrm{~A}$ & Hamilton & 2013 & SQ & - & - & 1 & $2 b$ & $0.00 \pm 0.00^{*}$ & $3.00 \pm 1.41 *$ & $2.67 \pm 0.82 *$ \\
\hline $13-522 \mathrm{C}$ & Levy & 2013 & WM & - & - & 1 & $2 b$ & $5.17 \pm 0.75$ & $6.00 \pm 0.63$ & $5.67 \pm 0.52$ \\
\hline $13-585$ & Suwannee & 2013 & WM & + & + & 2 & $2 \mathrm{a}$ & $7.50 \pm 1.22 * *$ & $6.17 \pm 1.17$ & $4.50 \pm 0.84$ \\
\hline $13-630 \mathrm{~A}$ & Levy & 2013 & WM & - & - & 1 & $2 b$ & $4.67 \pm 0.52$ & $7.00 \pm 0.63$ & $6.50 \pm 1.05^{* *}$ \\
\hline $13-\mathrm{C} 1$ & Hendry & 2013 & WM & - & - & 1 & $2 b$ & $5.50 \pm 0.84$ & $5.83 \pm 0.41$ & $5.50 \pm 0.55$ \\
\hline $13-\mathrm{C} 2$ & Hendry & 2013 & WM & - & - & 1 & $2 b$ & $6.00 \pm 0.63$ & $6.17 \pm 0.41$ & $5.17 \pm 0.98$ \\
\hline $14-31 S$ & Collier & 2014 & WM & - & - & 1 & $2 b$ & $6.50 \pm 0.55$ & $7.83 \pm 0.41$ & $6.67 \pm 1.03^{*}$ \\
\hline $14-32$ & Collier & 2014 & WM & - & - & 1 & $2 b$ & $6.00 \pm 0.89$ & $5.17 \pm 1.17$ & $4.83 \pm 1.17$ \\
\hline $14-410$ & Alachua & 2014 & WM & - & - & 1 & $2 b$ & $6.67 \pm 1.21$ & $6.00 \pm 1.41$ & $6.00 \pm 1.67$ \\
\hline 14-Gil & Gilchrist & 2014 & WM & - & - & 1 & $2 b$ & $5.00 \pm 2.19$ & $5.17 \pm 1.94$ & $5.00 \pm 0.00$ \\
\hline 14-Pol & Suwannee & 2014 & WM & - & - & 1 & $2 b$ & $6.17 \pm 1.72$ & $5.50 \pm 1.05$ & $5.17 \pm 0.41$ \\
\hline 14-SQI & Collier & 2014 & SQ & - & - & 1 & $2 b$ & $2.67 \pm 1.51 *$ & $4.00 \pm 1.26^{*}$ & $3.83 \pm 1.47$ \\
\hline 14-WMA & Collier & 2014 & WM & - & - & 1 & $2 b$ & $6.00 \pm 2.10$ & $7.00 \pm 1.10$ & $5.67 \pm 0.82$ \\
\hline 14-WMC & Collier & 2014 & WM & - & - & 1 & $2 b$ & $5.67 \pm 0.82$ & $6.83 \pm 1.47$ & $7.00 \pm 0.63 * *$ \\
\hline 14-WMI & Collier & 2014 & WM & - & - & 1 & $2 b$ & $6.50 \pm 0.84$ & $6.33 \pm 1.03$ & $5.50 \pm 0.55$ \\
\hline
\end{tabular}

a Fluorescence (Fluor) was assessed under UV light using a 48-h culture grown on King's medium B agar. INA = ice nucleation activity, Hap = haplotype, and Phyl = phylogroup.

${ }^{\mathrm{b}}$ Mean severity rating and standard deviation from 0 to 8 taken 21 days after inoculation, $n=6$ plants per strain-host combination. Asterisks indicate a severity rating was significantly lower $(*)$ or significantly greater $(* *)$ than the overall mean severity based on a nonparametric analysis of means for each host $(\alpha=0.05)$ The overall mean severity rating for each host is shown in parentheses.

c All counties listed are located in Florida, with the exception of Tift County in Georgia. 
approximately $1 \times 10^{8} \mathrm{CFU} \mathrm{ml}^{-1}$. Each plant was spray inoculated with the bacterial suspension until run-off, placed in a transparent plastic bag for $72 \mathrm{~h}$, and maintained in the greenhouse with average temperature at $24 \pm 4{ }^{\circ} \mathrm{C}$ and 70 to $90 \%$ relative humidity. The negative control consisted of plants sprayed with sterile tap water. Three weeks after inoculation, the total proportion of necrotic or symptomatic leaf tissue was rated from 0 to 8 using a modified Horsfall-Barratt scale (Horsfall and Barratt 1945) where $0=$ no symptoms and $1=1$ to $3,2=3$ to $6,3=6$ to $12,4=12$ to $25,5=25$ to $50,6=50$ to $75,7=75$ to 87 , and $8=87$ to $100 \%$ symptomatic. Three replications were included for each strain-host combination and the experiment was carried out twice. For confirmation of Koch's postulates, symptomatic leaf tissue was collected from a subset of plants at the end of the experiment and bacterial strains were reisolated from plant tissue according to the method described above. To test for differences in virulence among the two $P$. syringae haplotypes collected in this study, data were subjected to a two-way nonparametric analysis of variance with weighted means for unequal sample sizes. Pairwise comparisons were made with Tukey's honestly significant difference $(\alpha=0.05)$ and all statistical analysis was conducted using JMP Pro 13 (SAS Institute, Cary, NC).

\section{Results}

Identification and phenotypic characterization. Twenty-eight bacterial strains were collected from nine counties in Florida and one in Georgia between 2013 and 2014 (Table 1). All strains were identified as members of the Pseudomonas genus through sequence analysis of the 16S rRNA and were levan positive, oxidase negative, nonsoft rotting on potato, andarginine dihydrolase negative and produced an HR on tobacco after $24 \mathrm{~h}$ (data not shown). Variability was observed in the fluorescence and INA of the collected strains (Supplementary Fig. S1): 20 were nonfluorescent and INA negative, whereas the eight fluorescent strains were INA positive (Table 1). In the copper resistance assays, all strains behaved similarly to the sensitive control ( $P$. syringae pv. tomato DC3000), with a minimum inhibitory concentration (MIC) of $\mathrm{CuSO}_{4} \cdot 5 \mathrm{H}_{2} \mathrm{O}$ of $40 \mu \mathrm{g} \mathrm{ml}^{-1}$, with the exception of strain 13-428, for which the MIC of $\mathrm{CuSO}_{4} \cdot 5 \mathrm{H}_{2} \mathrm{O}$ was $30 \mu \mathrm{g} \mathrm{ml}^{-1}$. The resistant control (P. syringae A1513) grew at all concentrations tested (data not shown).

MLST and analysis. MLST identified two haplotypes among the collected strains; the 20 nonfluorescent strains were assigned to haplotype 1 and 8 fluorescent strains to haplotype 2 (Table 1). Additionally, a BLAST search of the NCBI database identified $P$. syringae strains CC457 and HS191 to be identical to multilocus haplotype 1 at the four sequenced loci. Multilocus sequence analysis (MLSA) of the concatenated housekeeping genes was consistent with previous studies, and all clades were well defined, with bootstrap support of $92 \%$ or greater (Bull et al. 2011; Hwang et al. 2005). The maximum-likelihood phylogeny indicated that the collected strains were members of $P$. syringae phylogroup 2 , whereby haplotype 1 clustered in clade $2 \mathrm{~b}$ and haplotype 2 in clade $2 \mathrm{a}$ (Berge et al. 2014; Bull and Koike 2015). Members of the 2 b clade included other genetically diverse cucurbit pathogens previously isolated in the United States over various years and strains recovered from unrelated hosts. Haplotype 1 branched from the pathotype strain $P$. syringae pv. syringae LMG1247; however, it also clustered with the $P$. syringae pvs. aptata CFBP1617, lapsa LMG2206, japonica M301072, atrofaciens LMG5095, coryli NCPPB4273, and pisi NCPPB2585, which are also members of phylogroup $2 \mathrm{~b}$. Members of the $2 \mathrm{a}$ clade included $P$. syringae strains isolated as pathogens of unrelated hosts and a multilocus haplotype previously recovered in Florida, Georgia, and California from watermelon, cantaloupe, and squash over various years (Fig. 2; Table 2).

BOX-PCR fingerprinting. BOX-PCR has previously been used as a tool to identify clonal $P$. syringae populations (Bull and Koike 2015; Louws et al. 1994), and correlated with the genetic relatedness inferred through DNA-DNA hybridization or MLSA (Goldberg et al. 2006; Marques et al. 2008). The BOXA1R profiles obtained here confirmed that the two multilocus haplotypes each corresponded to genetically distinct clonal lineages. The banding patterns among the 20 strains in haplotype 1 were indistinguishable (Fig. 3) and, although these strains shared two common fragments with $P$. syringae pv. syringae HS191, they were clearly not identical (Supplementary Fig. S2). Among the eight strains from haplotype 2, these also displayed identical banding patterns, with the exception of 13-428, which lacked one approximately $4-\mathrm{kb}$ fragment and contained two additional bands not present in the others (Fig. 3).

Pathogenicity assays. The results from two independent greenhouse experiments were similar and the effect of experiment was not significant $(P=0.4758)$; therefore, the results were combined. All of the collected bacterial strains were found to be pathogenic on watermelon cultivar Wrigley, cantaloupe cultivar Aphrodite, and squash cultivar Conqueror III, with the exception of strain 13509A, which failed to produce lesions on watermelon. In general, the bacterial strains were moderately to highly virulent and 24 of the 28 strains produced a mean severity rating of 5.0 or greater on at least two hosts. The two strains originally isolated from squash (13-509A and 14-SQI) were weakly virulent, with average severity ratings significantly lower than the overall mean on three and two hosts, respectively $(P<0.05)$ (Table 1$)$. Symptoms typically appeared 3 days after inoculation and were similar to those previously described for $P$. syringae infecting watermelon, cantaloupe, and squash (Hopkins and Schenck 1972; Newberry et al. 2016). These included stunting, water soaking on the cotyledons, and circular

Table 2. Pseudomonas syringae strains isolated from symptomatic cucurbit tissue in the United States and France prior to 2013 included for phylogenetic analysis $^{\mathrm{a}}$

\begin{tabular}{|c|c|c|c|c|c|c|c|c|}
\hline \multirow[b]{2}{*}{ Strain } & \multirow[b]{2}{*}{ Host } & \multirow[b]{2}{*}{ Origin } & \multirow[b]{2}{*}{ Year } & \multirow[b]{2}{*}{ Source } & \multicolumn{4}{|c|}{ Accession number } \\
\hline & & & & & $\operatorname{gyrB}$ & $r p o \mathrm{D}$ & glt A & gap1 \\
\hline 03-19A & Cantaloupe & Florida & 2003 & Newberry et al. 2016 & KT625904 & KT625925 & KT625985 & KT625959 \\
\hline $03-113 \mathrm{~A}$ & Cantaloupe & Florida & 2003 & Newberry et al. 2016 & KT625906 & KT625926 & KT625987 & KT625961 \\
\hline $04-1$ & Watermelon & Georgia & 2004 & Newberry et al. 2016 & KT625896 & KT625912 & KT625977 & KT625951 \\
\hline $200-1$ & Squash & Georgia & 2000 & Newberry et al. 2016 & KT625901 & KT625924 & KT625982 & KT625956 \\
\hline BS2121 & Squash & California & 2006 & Newberry et al. 2016 & KT625885 & KT625927 & KT625966 & KT62593 \\
\hline BS3062 & Watermelon & California & 2011 & Newberry et al. 2016 & KT625895 & KT625936 & KT625976 & KT62595 \\
\hline 03-A13 & Cantaloupe & Florida & 2003 & Newberry et al. 2016 & КT625909 & KT625921 & KT625990 & KT625963 \\
\hline 02-B4 & Watermelon & Florida & 2002 & Newberry et al. 2016 & KT625911 & KT625923 & KT625992 & KT625965 \\
\hline CC94 & Cantaloupe & France & 1994 & Morris et al. 2000 & AVEA02000299 & AVEA02000508 & AVEA02000560 & AVEA02000519 \\
\hline $\mathrm{CC} 457$ & Cantaloupe & France & 2003 & Morris et al. 2010 & AVEB02000356 & AVEB02000313 & NZ_CP006256 & AVEB02000011 \\
\hline $99-3$ & Watermelon & Georgia & 1999 & Newberry et al. 2016 & KT625900 & KT625915 & KT625981 & KT625955 \\
\hline $11-0438$ & ND & Florida & 2011 & Newberry et al. 2016 & KT625908 & KT625920 & KT625988 & KT625962 \\
\hline $08-1$ & Watermelon & Florida & 2008 & Newberry et al. 2016 & KT625897 & KT625913 & KT625978 & KT625952 \\
\hline 1188 & Zucchini & California & $\mathrm{ND}$ & Hwang et al. 2005 & $\ldots$ & $\ldots$ & $\ldots$ & $\ldots$ \\
\hline $01-23-5$ & Watermelon & Florida & 2001 & Newberry et al. 2016 & KT625899 & KT625919 & KT625980 & KT625954 \\
\hline $99-1$ & Watermelon & Georgia & 1999 & Newberry et al. 2016 & KT625898 & KT625914 & KT625979 & KT625953 \\
\hline
\end{tabular}

${ }^{\mathrm{a}} \mathrm{ND}=$ not determined. 
necrotic lesions, as well as foliar blighting and marginal necrosis on the true leaves, which progressed over time. On watermelon, lesions were gray to black and often surrounded by a chlorotic halo whereas, on squash, they initially appeared as yellow spots accompanied by vein clearing. Necrotic brown lesions were observed on cantaloupe and, as expected, no symptoms developed on the seedlings sprayed with sterile tap water. Bacterial strains were reisolated from a subset of symptomatic leaf tissue and the identity of the recovered strains was confirmed based on the ability to fluoresce on $\mathrm{KB}$ and sequence analysis of gyrB (Hwang et al. 2005). No bacterial strains identified as $P$. syringae were isolated from the negative controls. A two-way nonparametric analysis of variance showed significant differences

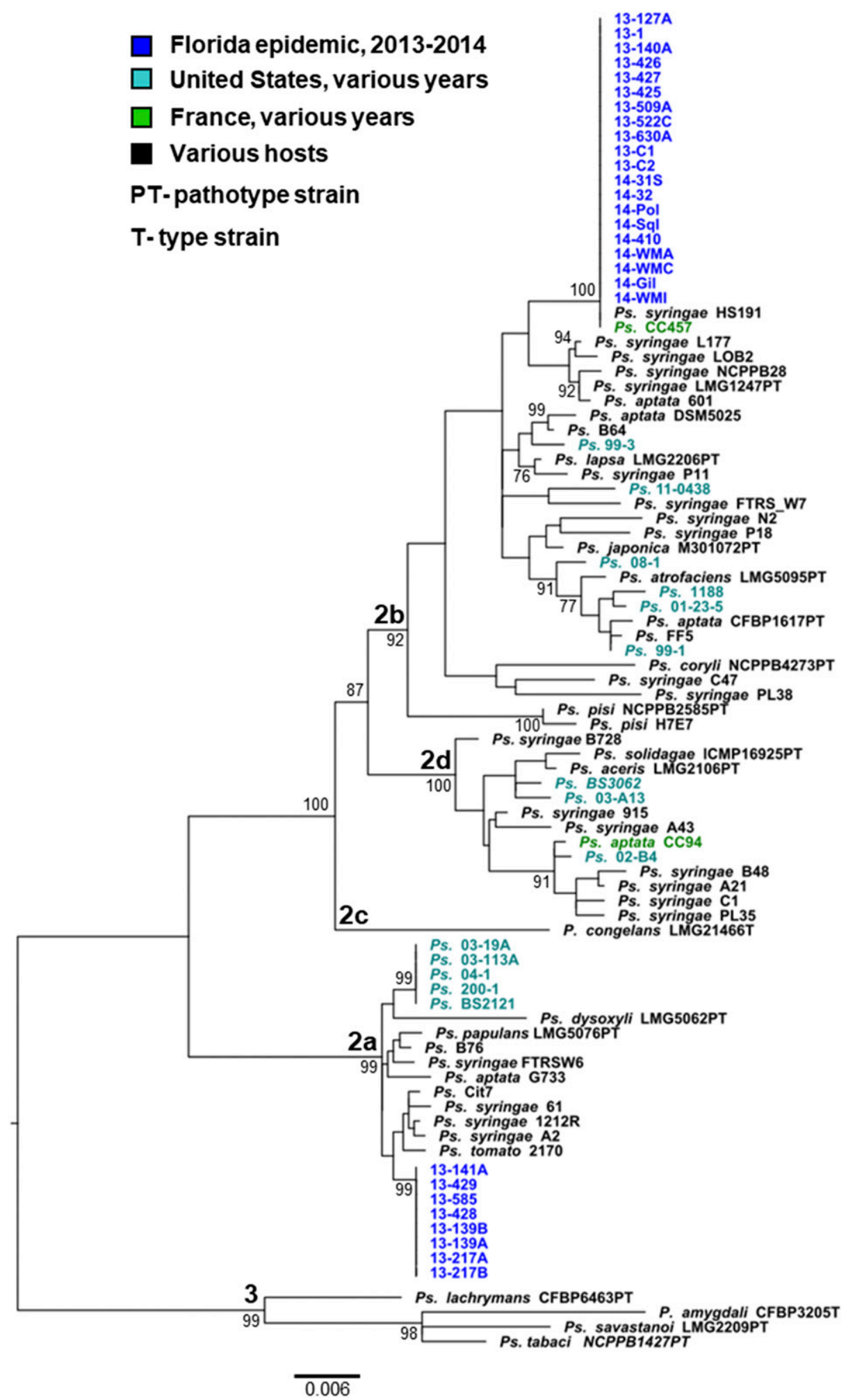

Fig. 2. Maximum-likelihood phylogeny based on an alignment of four concatenated housekeeping gene fragments-gyrB, rpoD, gap 1 , and gltA $(2,010 \mathrm{bp})-$ for $86 \mathrm{strains}$ of $P$ seudomonas syringae phylogroup 2 and four strains of phylogroup 3 (P. syringae pv. lachrymans, $P$. amygdali, $P$. savastanoi, and $P$. syringae pv. tabaci). Strains isolated from symptomatic tissue of watermelon, cantaloupe, or squash are labeled based on their collection, and the phylogroups are labeled at the node of each clade (Bull and Koike 2015). The pathovar designation of the type (T), pathotype (PT), and other reference strains is listed where available. The scale bar indicates the number of substitutions per site and bootstrap values greater than $75 \%$ are shown. 
in the virulence between the two haplotypes $(P<0.0001)$. Strain $13-509 \mathrm{~A}$ was excluded from this analysis because it was weakly virulent or nonpathogenic on the three hosts. Multilocus haplotype 2 was highly virulent on watermelon and produced a significantly greater mean severity rating (6.96) than haplotype 1 (5.83). In contrast, haplotype 2 was moderately virulent on squash, with a mean severity rating of 4.51, whereas haplotype 1 was highly virulent on this host (5.70). Both haplotypes were highly virulent on cantaloupe, and no significant differences between the mean severity ratings were observed on this host (Fig. 4).

\section{Discussion}

$P$. syringae is a genetically diverse pathogen of various cucurbit species and known to be disseminated through multiple sources into agricultural ecosystems (Monteil et al. 2016; Newberry et al. 2016; Słomnicka et al. 2015). A polyphasic characterization of the $P$. syringae population isolated from fields of diseased watermelon and squash throughout Florida revealed the presence of two clonal $P$. syringae lineages associated with recent disease outbreaks. Haplotype 1 was the most widely distributed and recovered from nine different Florida and Georgia counties between 2013 and 2014, whereas haplotype 2 was recovered from Suwannee, Alachua, and St. Johns Counties in 2013 (Table 1). All 20 strains which composed haplotype 1 displayed a unique phenotype, in that they were nonfluorescent on $\mathrm{KB}$ and negative for ice-nucleating ability (Table 1). These strains also displayed identical BOXA1R fragment patterns, indicating that they represent a genotypically uniform $P$. syringae population (Fig. 3 ). Haplotype 2 included eight fluorescent and ice-nucleating strains that also displayed identical BOXA1R fragment patterns, except for strain 13-428, which was similar but exhibited variation (Fig. 3).

Pathogenicity analysis showed that watermelon, cantaloupe, and squash seedlings were susceptible to a majority of the collected strains (Table 1). In general, both haplotypes were capable of producing moderate to high levels of disease severity on the three hosts; however, it was interesting to note differences in virulence between them. Despite being less prevalent, haplotype 2 was more virulent on watermelon than haplotype 1 yet produced only moderately severe disease on squash and was less virulent on this host. No obvious differences in virulence between the two haplotypes were observed on cantaloupe seedlings, which were also highly susceptible (Fig. 4). It was interesting to note that strain 13-509A failed to induce bacterial leaf spot symptoms on watermelon and was weakly virulent in general (Table 1); however, it could not be distinguished from other highly virulent strains using MLST or BOX-PCR (Table 1; Fig. 3). It is possible that there may be a genetic determinant, independent of the evolution of the core genome (i.e., plasmid or type 3 secreted effector), responsible for this qualitative difference in pathogenicity. Of more practical relevance, all of the strains examined here were found to be sensitive to copper in vitro, which is one of the few management options currently available for the disease (Newberry et al. 2017).

The two multilocus haplotypes collected here were found to be members of $P$. syringae phylogroup 2 and related to other $P$. syringae strains isolated from diverse plant species in clades $2 \mathrm{a}$ and $2 \mathrm{~b}$ (Fig. 2). Therefore, it was curious to identify from the NCBI database two other $P$. syringae strains that were identical to multilocus haplotype 1 and associated with both similar and unrelated plant diseases (Fig. 2). These included $P$. syringae strain $\mathrm{CC} 457$, which was isolated from symptomatic cantaloupe in France nearly a decade before the epidemics in Florida (Morris et al. 2010), and P. syringae pv. syringae HS191, which was recovered in Australia from diseased proso millet in 1969 (Gross and DeVay 1977; Ravindran et al. 2015). Interestingly, both of these strains were also reported to be non-ice nucleating, and a 2-kb truncation in the gene which encodes the outer membrane protein that serves as a nucleus for ice crystal formation was found in the genome of $P$. syringae pv. syringae HS191 (Berge et al. 2014; Ravindran et al. 2015). This suggests that this trait was

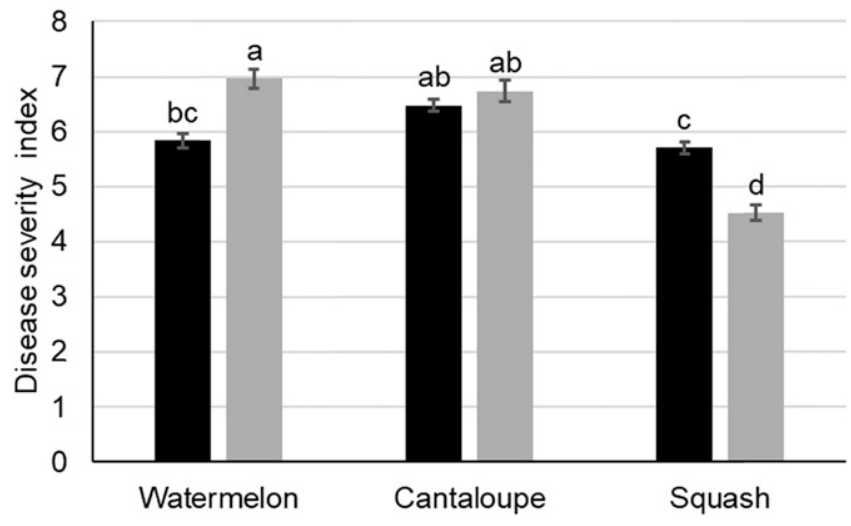

Fig. 4. Mean bacterial leaf spot severity on a scale of zero to eight on watermelon cultivar Wrigley, cantaloupe cultivar Aphrodite, and squash cultivar Conqueror III among the two Pseudomonas syringae haplotypes collected from the 2013-14 epidemic. Multilocus haplotype 1 is indicated in black $(n=114)$ and haplotype 2 in gray $(n=48)$. Error bars indicate the standard error of the mean and letters over the bars show significant differences (Tukey's honestly significant difference, $\alpha=$ 0.05).

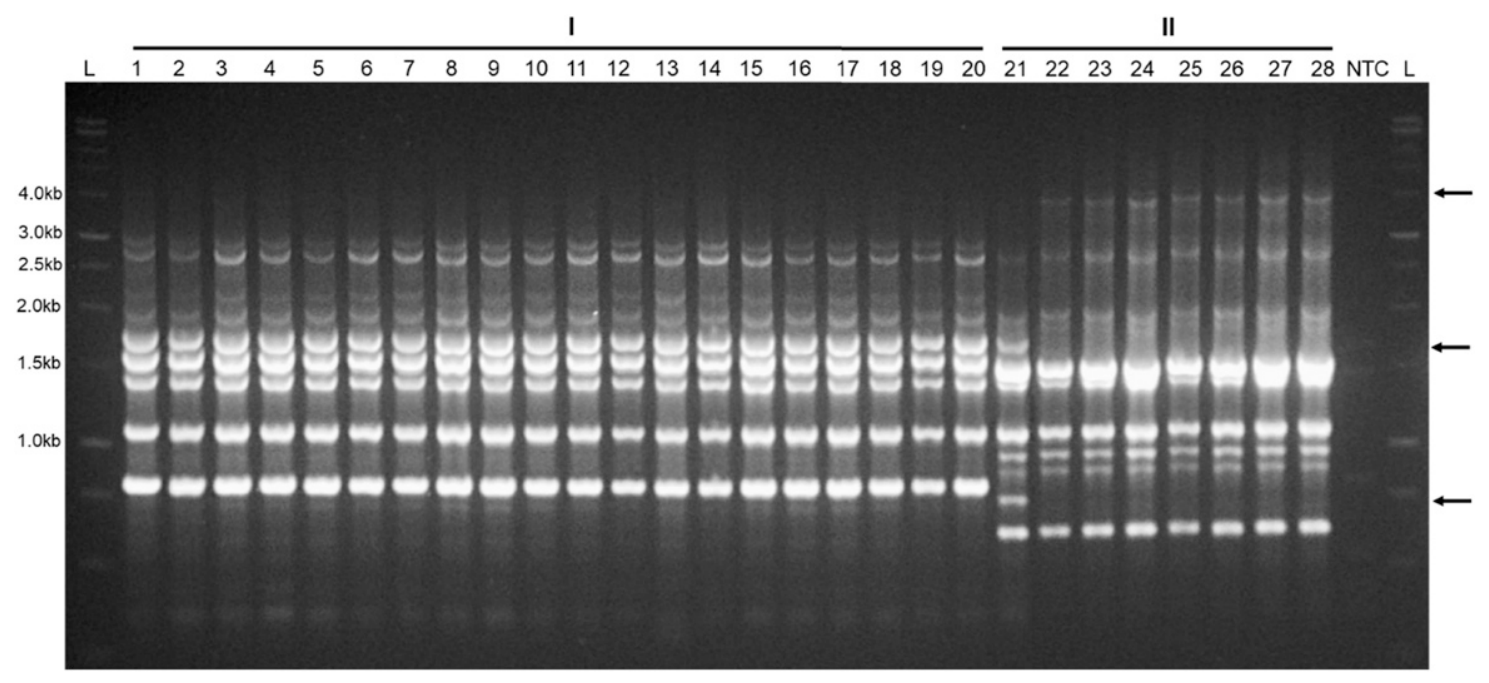

Fig. 3. BOX-polymerase chain reaction profiles of the Pseudomonas syringae strains collected from the 2013-14 Florida epidemic. Lane L shows the 1-kb ladder (Sigma-Aldrich) and NTC indicates the nontemplate control. Strains are grouped according to their multilocus sequence type: samples 1 to $20: 13-1,13-140 \mathrm{~A}, 13-\mathrm{C} 1,13-\mathrm{C} 2,13-127 \mathrm{~A}, 13-425$, 13-426, 13-427, 13-509A, 13-522C, 13-630A, 14-31S, 14-32, 14-WMA, 14-WMC, 14-WMI, 14-Pol, 14-Gil, 14-410, and 14-SQI, respectively (group I); and samples 21 to 28: 13-428 13-429, 13-139A, 13-139B, 13-141A, 13-217A, 13-217B, and 13-585, respectively (group II). Arrows show fragments discerning strain 13-428 (sample 21) from other members of group II. 
inherited vertically among strains of this lineage, and is atypical because members of $P$. syringae phylogroup 2 are often active for ice nucleation (Berge et al. 2014).

The genetic homogeneity among the $P$. syringae population recovered in this study contrasted with the diversity among other $P$. syringae strains isolated as cucurbit pathogens previously in the United States (Fig. 2). The identification of a single clonal P. syringae lineage (haplotype 1) distributed throughout Florida and isolated from production fields in the state located nearly $800 \mathrm{~km}$ apart indicated that this lineage was recently introduced into major Florida watermelon production areas (Fig. 1), likely occurring through either contaminated seed or watermelon transplants. The second clonal lineage (haplotype 2) identified here branched from another genetically uniform group of strains in phylogroup 2a that were predominantly associated with the disease in the United States prior to 2013 (Fig. 2; Table 2). Therefore, it was unclear whether this may represent an endemic $P$. syringae population, or whether haplotype 2 was also recently introduced into Florida.

Although $P$. syringae phylogroup 2 comprises 11 recognized pathovars associated with diseases of diverse plant families (Bradbury 1986; Bull and Koike 2015), members of this phylogenetic species are often identified as $P$. syringae pv. syringae based on the production of the lipodepsinonapeptide plant toxin syringomycin (Berge et al. 2014; Young 2010). P. syringae pv. syringae possesses a notoriously large and undefined host range (Bradbury 1986; Young 2010), yet differences in pathogenicity and virulence have been documented among individual strains within $P$. syringae phylogroup 2 (Maraite and Weyns 1997; Ravindran et al. 2015). In preliminary pathogenicity testing, we inoculated $P$. syringae pv. syringae HS191 on watermelon and squash and found that it was capable of producing necrotic lesions; however, these did not expand into the foliar blighting induced by some of the highly virulent strains isolated from watermelon (data not shown). The BOXA1R banding profiles among the strains collected in this study were similar but not identical to $P$. syringae pv. syringae HS191; therefore, whole-genome comparisons may provide relevant insights into the evolution of these strains as epidemic pathogens of watermelon and squash.

In Florida, there are approximately 10 major transplant production facilities which produce over 1 billion vegetable seedlings per year (McAvoy and Ozores-Hampton 2015). Therefore, these disease outbreaks could not have been caused by a single introduction of the pathogen. It is likely that an unresolved taxonomy, coupled with phenotypic and genotypic heterogeneity, have enabled virulent $P$. syringae strains to go undetected in cucurbit propagating material, especially because these strains cannot be differentiated from pathogens of unrelated hosts based on the evolution of the core genome at the four housekeeping gene fragments analyzed here (Fig. 2). Following the spring 2014 season, bacterial leaf spot did not reoccur on watermelon or squash in Florida; however, it was reported in Georgia watermelon fields and from watermelon transplants in North Carolina (Dutta et al. 2016; Quesada-Ocampo 2016). This highlights a need for the development of a specific diagnostic assay for members of $P$. syringae phylogroup 2 which pose a risk to cucurbit production, so as to limit their dissemination through contaminated seed or transplants.

\section{Acknowledgments}

This research was supported by the Southern IPM Center, Florida Watermelon Association, and the National Watermelon Association. We thank B. Hochmuth and A. Drew, horticultural agents of the University of Florida Cooperative Extension, for their help in scouting and collection of samples from the field; and R. Gitaitis and B. Dutta for providing P. syringae strains from Georgia.

\section{Literature Cited}

Andersen, G. L., Menkissoglou, O., and Lindow, S. E. 1991. Occurrence and properties of copper-tolerant strains of Pseudomonas syringae isolated from fruit trees in California. Phytopathology 81:648-656.

Berge, O., Monteil, C. L., Bartoli, C., Chandeysson, C., Guilbaud, C., Sands, D. C., and Morris, C. E. 2014. A user's guide to a data base of the diversity of Pseudomonas syringae and its application to classifying strains in this phylogenetic complex. PLoS One 9:e105547.
Bradbury, J. F. 1986. Guide to Plant Pathogenic Bacteria. CAB International Mycological Institute, Kew, UK.

Bull, C. T., Clarke, C. R., Cai, R., Vinatzer, B. A., Jardini, T. M., and Koike, S. T. 2011. Multilocus sequence typing of Pseudomonas syringae sensu lato confirms previously described genomospecies and permits rapid identification of $P$. syringae pv. coriandricola and $P$. syringae pv. apii causing bacterial leaf spot on parsley. Phytopathology 101:847-858.

Bull, C. T., and Koike, S. T. 2015. Practical benefits of knowing the enemy: Modern molecular tools for diagnosing the etiology of bacterial diseases and understanding the 117 taxonomy and diversity of plant pathogenic bacteria. Annu. Rev. Phytopathol. 53:157-180.

Burnham, K. P., and Anderson, D. R. 2004. Multimodel inference understanding AIC and BIC in model selection. Sociol. Methods Res. 33:261-304.

Dutta, B., Gitaitis, R. D., Driver, J. E., and Smith, S. 2016. First report of bacterial leaf spot on watermelon caused by Pseudomonas syringae pv. syringae in Georgia. Plant Dis. 100:518.

Elwakil, W. M., and Mossler, M. A. 2013. Florida Crop/Pest Management Profile: Watermelon. Publication number CIR1236. Cooperative Extension Service, Institute of Food and Agricultural Sciences, University of Florida, Gainesville, FL.

Fatmi, M., Bougsiba, M., and Hosni, T. 2008. Angular leaf spot of cucurbits: A bacterial disease in expansion in Morocco. Pages 381-390 in: Pseudomonas syringae Pathovars and Related Pathogens-Identification, Epidemiology and Genomics. M. B. Fatmi, A. Collmer, N. S. Lacobellis, J. W. Mansfield, J. Murillo, N. W. Schaad, and M. Ullrich, eds. Springer, Dordrecht, The Netherlands.

Feil, H., Feil, W. S., Chain, P., Larimer, F., DiBartolo, G., Copeland, A., and Lindow, S. E. 2005. Comparison of the complete genome sequences of Pseudomonas syringae pv. syringae B728a and pv. tomato DC3000. Proc. Natl. Acad. Sci. USA 102:11064-11069.

FDACS. 2012. Florida Agriculture by the Numbers. Online publication. Florida Department of Agriculture and Consumer Services (FDACS), Tallahassee, FL. https://www.nass.usda.gov/Statistics_by_State/Florida/Publications/ Annual_Statistical_Bulletin/2012/E1thru18Veg-2012.pdf

FDACS. 2014. Florida Agriculture by the Numbers. Florida Department of Agriculture and Consumer Services (FDACS), Tallahassee, FL. https://www. nass.usda.gov/Statistics_by_State/Florida/Publications/Annual_Statistical_Bulletin/ 2014/E1 thru18Veg-2014.pdf

Goldberg, T. L., Gillespie, T. R., and Singer, R. S. 2006. Optimization of analytical parameters for inferring relationships among Escherichia coli isolates from repetitive-element PCR by maximizing correspondence with multilocus sequence typing data. Appl. Environ. Microbiol. 72:6049-6052.

Gross, D. C., and DeVay, D. C. 1977. Population dynamics and pathogenesis of Pseudomonas syringae in maize and cowpea in relation to the in vitro production of syringomycin. Phytopathology 67:475-483.

Gürtler, V., and Stanisich, V. A. 1996. New approaches to typing and identification of bacteria using the 16S-23S rDNA spacer region. Microbiol. 142:3-16.

Harighi, B. 2007. Angular leaf spot of cucumber caused by Pseudomonas syringae pv. lachrymans in Kurdistan. Plant Dis. 91:769.

Hopkins, D. L., and Schenck, N. C. 1972. Bacterial leaf spot of watermelon caused by Pseudomonas syringae pv. lachrymans. Phytopathology 62:542-545.

Horsfall, J. G., and Barratt, T. W. 1945. An improved system for measuring plant diseases. (Abstr.) Phytopathology 35:655.

Hwang, M. S. H., Morgan, R. L., Sarkar, S. F., Wang, P. W., and Guttman, D. S. 2005. Phylogenetic characterization of virulence and resistance phenotypes of Pseudomonas syringae. Appl. Environ. Microbiol. 71:5182-5191.

Lamichhane, J. R., Messean, A., and Morris, C. E. 2015. Insights into epidemiology and control of diseases of annual plants caused by the Pseudomonas syringae species complex. J. Gen. Plant Pathol. 81:331-350.

Langston, D. B., Sanders, F. H., Brock, J. H., Gitaitis, R. D., Flanders, J. T., and Beard, G. H. 2003. First report of a field outbreak of a bacterial leaf spot of cantaloupe and squash caused by Pseudomonas syringae pv. syringae in Georgia. Plant Dis. 87:600.

Lelliott, R. A., Billing, E., and Hayward, A. C. 1966. A determinative scheme for the fluorescent plant pathogenic pseudomonads. J. Appl. Bacteriol. 29:470-489.

Louws, F. J., Fulbright, D. W., Stephens, C. T., and de Bruijn, F. J. 1994. Specific genomic fingerprints of phytopathogenic Xanthomonas and Pseudomonas pathovars and strains generated with repetitive sequences and PCR. Appl. Environ. Microbiol. 60:2286-2295.

Maraite, H., and Weyns, J. 1997. Pseudomonas syringae pv. aptata and pv. atrofaciens, specific pathovars or members of pv. syringae? Pages 515-520 in: Pseudomonas syringae Pathovars and Related Pathogens: Identification and Taxonomy. K. Rudolph, T. J. Burr, J. W. Mansfield, D. Stead, V. A. Kietzell, and J. Kietzell, eds. Kluwer Academic Publishers, Dordrecht, The Netherlands.

Marques, A. S. A., Marchaison, A., Gardan, L., and Samson, S. 2008. BOXPCR-based identification of bacterial species belonging to Pseudomonas syringae-P. viridiflava group. Genet. Mol. Biol. 31:106-115.

McAvoy, G., and Ozores-Hampton, M. 2015. Florida Crop/Pest Management Profile: Commercial Transplant Production in Florida. Publication number HS714. Cooperative Extension Service, Institute of Food and Agricultural Sciences, University of Florida, Gainesville, FL.

Menkissoglu, O., and Lindow, S. E. 1991. Chemical forms of copper on leaves in relation to bactericidal activity of cupric hydroxide deposits on plants. Phytopathology 81:1263-1270. 
Monteil, C. L., Yahara, K., Studholme, D. J., Mageiros, L., Méric, G., Swingle, B., Morris, C. E., Vinatzer, B. A., and Sheppard, S. K. 2016. Population-genomic insights into emergence, crop adaptation and dissemination of Pseudomonas syringae pathogens. Microb. Genomics. 2. doi:10.1099/mgen.0.000089

Morris, C. E., Glaux, C., Latour, X., Gardan, L., Samson, R., and Pitrat, M. 2000. The relationship of host range, physiology, and genotype to virulence on cantaloupe in Pseudomonas syringae from cantaloupe blight epidemics in France. Phytopathology 90:636-646.

Morris, C. E., Sands, D. C., Vanneste, J. L., Montarry, J., Oakley, B., Guilbaud, C., and Glaux, C. 2010. Inferring the evolutionary history of the plant pathogen Pseudomonas syringae from its biogeography in headwaters of rivers in North America, Europe, and New Zealand. MBio 1:e00107-10.

Mullin, I., and Schenck, N. C. 1963. Bacterial leaf spot on watermelon. Plant Dis. Rep. 47:848.

Nei, M., and Kumar, S. 2000. Molecular Evolution and Phylogenetics. Oxford University Press, New York.

Newberry, E. A., Jardini, T. M., Rubio, I., Roberts, P. D., Babu, B., Koike, S. T., Bouzar, H., Goss, E. M., Jones, J. B., Bull, C. T., and Paret, M. L. 2016. Angular leaf spot of cucurbits is associated with genetically diverse Pseudomonas syringae strains. Plant Dis. 100:1397-1404.

Newberry, E. A., Paret, M. L., Jones, J. B., Ritchie, L., Freeman, J. H., Dufault, N. S., Babu, B., Goss, E. M., Vallad, G. E., Roberts, P. D., and Hochmuth, B. 2015. Characterization of Pseudomonas syringae associated with watermelon and squash disease outbreaks in Florida and Georgia. (Abstr.) Phytopathology 105:S2.8.

Newberry, E. A., Ritchie, L., Babu, B., Sanchez, T., Beckham, K., Jones, J. B., Freeman, J. H., Dufault, N. S., and Paret, M. L. 2017. Epidemiology and management of bacterial leaf spot on watermelon caused by Pseudomonas syringae. Plant Dis. 101:1222-1229.

Quesada-Ocampo L. 2016. Pseudomonas leaf spot reported on watermelon transplants. Online publication. North Carolina Cooperative Extension 124. https://plantpathology.ces.ncsu.edu/2016/05/pseudomonas-leaf-spot-reportedon-watermelon-transplants/

Ravindran, A., Jalan, N., Yuan, J. S., Wang, N., and Gross, D. C. 2015. Comparative genomics of Pseudomonas syringae pv. syringae strains B301D and HS191 and insights into intrapathovar traits associated with plant pathogenesis. MicrobiologyOpen 4:553-573.

Riffaud, C. H., and Morris, C. E. 2002. Detection of Pseudomonas syringae pv aptata in irrigation water retention basins by immunofluorescence colonystaining. Eur. J. Plant Pathol. 108:539-545.

Sarkar, S., and Guttman, D. S. 2004. Evolution of the core genome of Pseudomonas syringae, a highly clonal, endemic plant pathogen. Appl. Environ. Microbiol. 70:1999-2012.

Schaad, N. W., Mortensen, C. N., Li, J., Feng, J., Luo, L., Mazzaglia, A., and Balestra, G. M. 2014. Technical challenges for specific, sensitive detection of seed-borne bacterial pathogens. Pages 59-66 in: Global Perspectives on the Health of Seeds and Plant Propagation Material. Plant Pathology in the 21st Century (Contributions to the 9th International Congress), vol. 6. M. Gullino and G. Munkvold, eds. Springer, Dordrecht, The Netherlands.

Sedighian, N., Shams-Bakhsh, M., Osdaghi, E., and Khodaygan, P. 2014. Etiology and host range of bacterial leaf blight and necrosis of squash and muskmelon in Iran. J. Plant Pathol. 96:507-514.

Słomnicka, R., Olczak-Woltman, H., Bartoszewski, G., and Niemirowicz-Szczytt, K. 2015. Genetic and pathogenic diversity of Pseudomonas syringae strains isolated from cucurbits. Eur. J. Plant Pathol. 141:1-14.

Tamura, K., Stecher, G., Peterson, D., Filipski, A., and Kumar, S. 2013. MEGA6: Molecular evolutionary genetics analysis version 6.0. Mol. Biol. Evol. 30: 2725-2729.

USDA. 2013. U.S. Watermelon Industry (89029). Table 19. Online publication. United States Department of Agriculture Economic Research Service, Washington, DC. http://usda.mannlib.cornell.edu/usda/ers/89029/Table19.xls

Versalovic, J., Schneider, M., de Bruijn, F. J., and Lupski, J. R. 1994. Genomic fingerprint of bacteria using repetitive sequence-based polymerase chain reaction. Methods Cell Mol. Biol. 5:25-40.

Yamamoto, S. Kasai, H. Arnold, D. L., Jackson, R. W. Vivian, A., and Harayama, S. 2000. Phylogeny of the genus Pseudomonas: Intrageneric structure reconstructed from the nucleotide sequences of $g y r \mathrm{~B}$ and $r p o \mathrm{D}$ genes. Microbiology 146:2385-2394.

Young, J. M. 2010. Taxonomy of Pseudomonas syringae. J. Plant Pathol. 92:S5-S14 